\title{
The Relevance of the Indigenous African Moral Theory in the control of Public Sector Corruption in Kenya
}

\author{
Joseph Ouma Oindo $^{1}$, Dr. Zacharia Samita ${ }^{2}$, Prof. Edward Oyugi ${ }^{3}$ \\ ${ }^{1,}$, Tangaza University College, Kenya \\ ${ }^{2}$ Kenyatta University, Kenya
}

\begin{abstract}
This paper explores the contribution of African moral theory in the control of public sector corruption in Kenya. This study is based on a literature review method. The principle method used is the documentary analysis that show how African moral theory can be applicable to the development of a national ideology of the common good to curb persistent corruption in Kenya. This study could provide the Government of Kenya with important information relating to how public sector corruption can be controlled through ethical formation that is indigenous to Kenyans. Through documentary analysis, the study found out that African ethics resonates with the indigenous worldview of Africans and can effectively be employed as an anti-corruption initiative in Kenya. This is because, the central premise of African moral theory is harmony and positive relationships. However, corruption distorts harmony and leads to negative relationships in the country. The study recommends an induction program for government employees. This induction program is a value-reorientation program delivered through seminars/workshops with a particular focus on honesty, justice, transparency, fairness, and personal integrity. The study also recommends the use of reward system as well as deterrents.
\end{abstract}

Key Terms: Values, Ubuntu, Common Good, Ethics, Educational Curriculum

\section{BACKGROUND TO THE STUDY}

$\mathrm{T}$ he contemporary African society has been described by scholars as a morally fallen world (Kinoti, 1992). For Mugambi and Nasimiyu (1992), the present African society contrasts sharply with the previous society as far morality is concerned. Whereas in the past Africans were much more community-centred, today they are becoming more and more ego-centred (Mwikamba, 1992) and it is this pervasive individualism that has precipitated to persistent public sector corruption leading to the exploitation of the masses. For the case of Tanzania, corruption is cited as one of the major constraints for doing business (Lindner, 2014). Since these immoral incidents are being practiced by educated people, Ngussa, Makewa and Allida (2016) argued, albeit theoretically, that there is a high demand for the education system in Tanzania to come up with strategies to rescue the situation.

For the Kenyan context, moral degeneration is multifaceted and manifests itself in all sectors of the society. Corruption in Kenya has led to the general collapse of the public sector and a leading cause of human suffering. A recent report by the Ethics and Anti-Corruption Commission (EACC, 2016) showed that at the national government level, the ministry of Interior and Coordination of National Government $(45.9 \%)$ was ranked highest as one of the most prone to corruption followed by the ministry of health (33\%), devolution and planning (19.3\%), education, Science and Technology (19.2\%), Transport and Infrastructure (15.5\%), Land, housing and urban development (15.1\%), and Finance (8.3\%). Among government agencies, Kenya Police Service $(30.2 \%)$ emerged top in corruption, followed by traffic police (29\%), National Government Administration Office, formally Provincial Administration (22.8\%), and Public Hospitals (9.7\%). At the County Government level, County Health Services (37.4\%) ranked first, followed by County Public Works and Services (22.5\%), and Education and Child Care (15.4\%). Moreover, nationally, delays in service delivery $(51.3 \%)$, bribery $(44.5 \%)$, conflict of interest $(38.5 \%)$, discrimination $(38.1 \%)$, and criminal activities such as fraud, theft and embezzlement (37.4\%) were rated as the most common unethical forms of conduct in Kenya. This report by the EACC (2016) essentially shows that corruption is pervasive in Kenya.

Amidst these pervasive corruption scandals, research also shows that corruption distorts markets, disrupts flow of goods and capital, and reduces economic growth. Corruption impedes sustainable development and perpetuates poverty. Coming to the realisation of the risks of corruption, worldwide associations and governments have proposed measures to control corruption. The United States through the sanctioning of the Foreign Corrupt Practices Act (FCPA) in 1977 condemned bribery. UNDP's Program on AntiCorruption for Development Effectiveness (PACDE) (20082013) was formed to handle the issue of corruption universally, however it ended on 31 December 2013 and was replaced by UNDP's Global Anti-Corruption Initiative (GAIN) (2014-2017), to help the execution of the United Nations Convention against Corruption (UNCAC), which tried to empower state parties to embrace public lawful instruments against corruption.

Moreover, corruption continues to be condemned globally particularly through the United Nations Convention 
Against Corruption, United Nations Declaration and Action Plan against Money Laundering and the Regional AntiCorruption Program for Africa (2011-2016) which is an initiative of the United Nations Economic Commission for Africa (UNECA) and the African Union Advisory Board on Corruption. These instruments have devised strategic approaches that often combines policy research and analysis as well as training and capacity development on the best practices for the control of corruption.

\section{Statement of the Problem}

Despite the efforts being made to curb corruption, both internationally and in Kenya, corruption continues to impede development and a major cause of social inequality in Kenya. In Kenya, the presence of an anti-corruption institution and parliamentary oversight bodies have had little or no effect in the control of public sector corruption. It is within this perspective that this present study argues that a rereading of the African indigenous moral system will be a valuable anti-corruption tool in Kenya. The African indigenous moral system, is understood as a system that encourages the common good and shuns individualism.

\section{Research objective}

To explore the relevance of African moral theory in the control of public sector corruption in Kenya.

\section{THEORETICAL FRAMEWORK}

African Moral Theory suggest that morality is conceivable only through association with others. Morality, from a steadfastly an African point of view, emerges from association/relationship with others. The inquiry now is unequivocally what sort of relationship is recommended. How should people relate to others? According to Tutu (1999), people should relate in such a way that properly values a certain cohesive relationship. "Harmony, friendliness, community are great goods. Social harmony is for us the summum bonum - the greatest good. Anything that subverts or undermines this sought-after good is to be avoided like the plague. Anger, resentment, lust for revenge, even success through aggressive competitiveness, are corrosive of this good" (Tutu 1999: 35). This means that harmony is the central aspect in African moral theory.

Considering the self as in relationship with others likewise includes participating in joint tasks or community projects. Life, to an African, is only meaningful if lived in relations with others. This implies that an amicable relationship involves showing fortitude towards others by emphatically adding to the improvement of the common good. This involves showing altruism or being emphatically considerate towards the benefit of all. It infers that in African ethics, individuals display altruism to the extent that they are cheerful when others prosper and pitiful when others wallow.

At this point of discussion, we can really say that the two aspects of African moral theory are generosity and relating to others in amicably. In relating to other people, an African regards associations with others to a degree that individuals not just consider themselves a 'we' occupied in some form of coordination, but we behave in ways supportive of others. To illustrate this point clearly, African moral theory demands that we do not just identify ourselves as 'Kenyans', that is, citizens of Kenya, but we behave in a manner that is supportive of the welfare of others.

On the other hand, this African moral theory prohibits individuals from being unfriendly. It prohibits people not only from isolating themselves from others or, worse, defining themselves in opposition to or subordinating them, which is divisive, but also from not caring about others' interests or, worse, expressing ill will by trying to harm them. What makes it wrong to be engaged in corruption related activities such as money laundering, manipulation of government accounts, etc., is that they consist of unfriendly behaviour because they go against the two principles of African moral theory: relationships and harmony.

\section{METHOD}

This study adopted a qualitative literature review method. Three steps were followed in the review: literature search and selection, analysis and reporting of the emerging themes. The literature that was included in this study specifically deal with issues of moral development, corruption and African moral theory.

\section{FINDINGS AND DISCUSSION}

By means of content analysis of the available literature with regard to an ethical solution to the persistent corruption in Kenya, this study established that corruption is a moral problem (Gyekye, 1997), and as such, it requires a cultivation of moral character in citizens (Kinoti, 1994; Bafinamene, 2016). Gyekye (1997) rightly opines that it is moral formation that will provide an enduring solution to the persistent problem of corruption within the continent. Africa needs persons of integrity, ability and education with a genuine concern for the wellbeing of all citizens. But, such persons must be created through careful character formation (Kinoti, 1994). In this regard, this paper found out that this character formation can essentially take place through value re-orientation, exemplary role models, and ethical education in institutions of learning.

\section{Value re-orientation}

The civil servants as well as the general public should understand that there are certain values which they ought to aim for. Such values as, honesty, justice, love, obedience, fairness, being content, personal integrity, respect, and so on should be encouraged among the civil servants against, dishonesty, discrimination, marginalization, injustice, hatred, and so on. The importance of putting the interest of the state above family and personal interests is also one of the ways of distinguishing higher and lower values. Doing this is very important for the development of a nation and so 
everybody ought to aspire to them. The civil servants ought to understand that there is nothing better than a good name and thus, should strive towards attaining this, so that those succeeding them will follow their foot-prints. When civil servants change to right behaviour in the public sector, it will be difficult for them to be involved in unethical practices. In other words, there must be an attitudinal change.

\section{Exemplary leadership role models}

As far as the Kenyan context is concerned, Odundo \& Ganira (2017) rightly opined that by acquiring values, children demonstrate awareness of themselves as constructive members of the society, through communicating openly and honestly with others. Hence, teachers have the responsibility of shaping the lives of children by inculcating appropriate values for behaviour transformation and ethical orientation. The authors rightly opined, albeit with no clear roadmap for moral education, that strengthening of Value Based Education (VBE) in schools provides an enabling platform for sustainable development and the realization of Kenya's Vision 2030. Hence the role of the schools entails equipping children with positive values that enhance responsibility and develops productive members of the society. Although this study concurs with Odundo \& Ganira (2017) on the role of schools in value education, it nevertheless opines that value education is not only the sole prerogative of the schools, but also a prerogative of the entire community, called Kenya.

It is expected that leaders at all government levels in the public sector should lead by good examples. Bad leadership remains one of the reasons why corruption is rampant in the public sector in Kenya. When leadership is good, corruption is bound to be low and when leadership is bad, corruption is bound to be high. Therefore, civil servants ought not to be greedy as this will cause them to be involved in corrupt practices. Leaders should be honest and avoid nepotism, clientelism and ethnic cronyism, for this is what is expected from good leadership. If leaders fail to show exemplary leadership and continue to abuse their offices, then, the general public will come to think that there is nothing wrong with corruption. When our leaders and bureaucrats become honest, corruption may not be high and equally the fight against corruption will be successful. Leaders should ensure that rules as provided by the government are followed by the civil servants and not be replaced with nepotism, clientelism and ethnic cronyism.

\section{Ethical education in institutions of learning}

A report by Women Educational Researchers in Kenya titled, Value-based Education in Kenya: An Exploration of Meanings and Practices (2015) contended that the examination focus of Kenya's educational system is a major deterrent to the development of a culture of values and ethics in and through schools. The report argued that the absence of values and ethical practices is the common cause associating acts of corruption, criminality and terrorism in Kenya on the one hand, and cultures of violence, abuse and impunity in educational institutions on the other. The report recommended an adoption of a whole school approach where the teaching and learning of positive values is seamless and reflected in the ethos of the schools, integration of four core values of respect, tolerance, equality and peace into the curriculum at all levels of education; elimination of the culture of mean score and certification; enforcement of policies and laws incorporating the four core values and aligning school rules with the values stipulated in the Kenyan constitution; and intensification of parental education and community sensitization on value-based education. However, conspicuously missing in the report is a clear road map on how the above mentioned core values should be taught in schools, assuming that they are already in the school curriculum. Although the Women Educational Researchers in Kenya (2015) preferred a whole school approach to moral development, this study argues that the moral theory that ought to be integrated into school curriculum in the institutions of learning, is a moral theory that is germane to Africans, that is, African indigenous moral theory.

There is a need for ethical education to every person, both children and adults, in Kenya. This ethical education ought to start from the pre-adolescents stage to the university level. At the tertiary level, ethics ought to be made a compulsory module for all the students. This is because they are the people who will soon be employed into the public sector. Ethical education should also be given to the new employees during orientation before they are posted to serve in order to make what constitutes corruption in the public sector clear to them. Ethical education also ought to be equally given to the older civil servants as a way of retraining them. Through ethical education, the civil servants and the entire public will understand the right thing to do and also the wrong thing to avoid. For instance, in recruitment and promotion exercises, that candidate should be selected based on merit, and the best qualified candidate must be taken before others. People should not be selected for jobs based on social connections.

\section{Strengthening Parent-Child Positive Communication}

Parents are the first role models in the moral development of children. The process of a child's moral development takes place in the atmosphere of norms, rules and moral principles which are followed by the parents (Langier, 2016). Bandura (1991) theorized that the moral standards to which adults subscribe, also guide the type of morality they teach to their children. This implies that for children to subscribe to values of common good, honesty, and transparency, the parents would first of all believe in such values. Similarly, positive communication within the family is also a predictor in children's moral development. Parent-child positive communication can be conceptualized in terms of empathy, reflective listening and supportive comments that enable families to be aware of each other's needs. Within the African setup, a family remains one of the most important centres of moral formation. It is within the family that the 
child acquires values and grows to distinguish between right and wrong. Majority of the ethnic communities in subSaharan Africa believe that it is the family that gives a child his or her identity. This identity is not just limited to a name, but encompasses values that are meant to promote harmony and foster positive relationships within the community.

\section{Strengthening Teacher-Student relationships}

Jevtic (2014) asserts that the theoretical solutions to ethical education have been tried for decades without really changing students' moral behaviour. He argued that the moral development of students does not depend primarily on the theoretical character education efforts but on the maturity and moral capacities of the teachers with whom students interact on a daily basis. It is the teachers' ability to appreciate students' perspectives and to disentangle them from their own, their ability to admit and learn from moral error, their moral energy and idealism, their generosity, and their ability to help students develop moral thinking without shying away from their own moral authority that determines the moral development of students.

Teacher-student relationship shapes students' moral development. In a positive school culture where children feel safe to talk to their teachers when they face problems, appreciated and involved in decision-making at school, encouraged to develop pro-social behaviours, encouraged to develop a culture of sharing, students eventually develop positive social behaviours. In contrast, in a toxic school culture characterized by blame, victimization and a lack on the part of teachers, students are lively to develop anti-social behaviours that are not necessarily geared towards the common good of the society.

Students will justify stealing, for example, because society is corrupt or because everybody is basically self-interested and the educators also lack moral capacity that students can copy. Many teachers do not possess moral qualities, and if they do, are unable to express such qualities in their interactions with students. Such teachers do not reach out to struggling students and do not attempt to see students' perspectives.

According to Petro (2014), moral values cannot effectively be taught as a subject in the formal curriculum in the same way as factual science is taught. Rather, moral values ought to form part of the consciousness of teachers who should deliberately make an effort to model learners' moral reasoning skills. More importantly, teachers ought to behave as morally accountable professionals and act as role models to students in the classroom, because students often internalize behaviour patterns which they observe from teachers rather than from subjects taught at a factual level.

\section{RECOMMENDATIONS}

This study recommends that the Kenya Public Service Commission develops an induction program for the newly recruited individuals in the public service. This is a training program that will seek to orient the new recruits into the national ethics, which this study has shown to be the African moral discourse of the common good. In this program, the civil servants will be made aware of the distinction between their obligations to the family and that of the State. There must be a very clear distinction between the civil servants' obligation to the state and their obligation to the family, friends and clientele. In other words, there should a general orientation by the State to make civil servants understand the difference between what he or she is supposed to do as a civil servant to the state and as a private individual to his or her family. The orientation should make civil servants to understand that once you are employed to work as an official on behalf of the state, you are officially to relate to every citizen equally. As such there should be no room for discrimination against anybody.

With regard to exemplary leadership role models, this paper recommends that the government could develop a program of rewarding those civil servants who have exhibited high levels of transparency with regard to public resources. However, the use of deterrents is also recommended in the control of public sector corruption in Kenya. Nepotism, clientelism and ethnic cronyism, are usually practiced through the traditional kinship system (Ouma, Oyugi \& Samita, 2021). The traditional kinship system, as practiced by Africans, expects members of the family to give help to each other so that nobody will lack. This is because of the kinship bonds which bind members together. As a result, it becomes bad for a member of the extended family to withhold giving support to their members. Moreover, in the communal system of living, people believe that charity according to the African dictum begins at home. This is probably why some of the people who indulge in corruption, especially in the public sector may do so unintentionally, thinking that it is good thing to do in the public office. Nevertheless, sometimes others do it intentionally. Most often, some people, especially in the public sector, may not see anything wrong in giving help to their family members or even friends whenever they have the opportunity to do so. Therefore, punishment should be given to those civil servants that involve themselves in corrupt practices related to kinship obligations. Civil servants ought to be punished whenever they recruit or use public resources for the benefit of their families, friends and clientele.

\section{CONCLUSION}

In attempt to respond to persistent corruption in Kenya, this present paper through a literature review, has argued that persistent corruption in Kenya is a moral problem. Despite the presence of anti-corruption institutions and laws, corruption continues to halt development in Kenya. This paper has found out that value-reorientation, exemplary leadership, and ethical education in institutions of learning, strengthening teacher-student relationships and strengthening family systems can be viable options through which the much needed moral formation can be effected in Kenya as a response to public sector corruption. 


\section{REFERENCES}

[1] Bafinamene C.K. (2016). Church and moral formation in an African context: A critical appropriation of Stanley Hauerwas' proposal. University of Pretoria.

[2] Bandura, A. (1991). Social cognitive theory of moral thought and action. In W. M. Kurtines \& J. L. Gewirtz (Eds.) Handbook of moral behaviour and development. New Jersey: Erlbaum.

[3] Ethics and Anti-Corruption Commission (EACC). (2016). National Ethics and Corruption Survey. Nairobi.

[4] Gyekye, K (1997). Political corruption: A philosophical analysis of a moral problem. Sankofa Publishing Co. Ltd.

[5] Jevtić, B. (2014). Teachers' pedagogical actions affecting the moral development of personality. Problems of Education in the 21 st Century, 58(67).

[6] Kinoti, W. H. (1992). African morality: past and present. (In Mugambi, J. Ndwiga Kanyua \& Nasimiyu- A. Wasike, (eds). Moral and ethical issues in African Christianity. Nairobi : Initiatives.

[7] Kinoti, G (1994). Hope for Africa: And what the Christian can do. AISRED.

[8] Langier, C. (2016). Moral upbringing of children in the context of transformations of modern families: An overview of issues.

[9] Lindner S (2014).Tanzania: Overview of corruption and anticorruption. U4 Expert Answers. www.transparency.org.
[10] Mugambi, J. N. \& Nasimiyu-Wasike, A. (1992). Moral and ethical issues in African Christianity; exploratory essays in moral theology. Nairobi: Initiatives.

[11] Mwikamba, C.M. (1992). Changing morals in Africa. In Mugambi, J.N.K. \& Nasimiyu- Wasike, A. (eds). Moral and ethical issues in African Christianity. Nairobi: Initiatives.

[12] Ngussa, M. B, Makewa N. L \& Allida, D. (2016). Integration of moral values in the secondary school humanities curriculum across Lake Zone, Tanzania. International Journal of Educational Policy Research and Review, 3 (7), 117-125.

[13] Odundo, P. A \& Ganira, K. L. (2017). Teacher Position in Spurring Value Based Education in Early Learning in Nairobi County, Kenya: Addressing Support of Values in School Environment. Journal of Education and Learning, 6(3), 194 - 203. doi:10.5539/jel.v6n3p194.

[14] Ouma, J, Oyugi, E \& Samita, Z. (2021). How African Kinship System Contributes to Corruption in Kenya, Open Journal of Social Sciences, 9, 21-38.

[15] Petro, N. (2014). Teachers and moral development of learners: A Case for a Kohlbergian and Neuroscience Approach. Mediterranean Journal of Social Sciences, 5(4).

[16] Tutu, D. (1999). No Future without Forgiveness. New York: Random House, Inc. 